\title{
Review
}

Dev Neurosci 2009;31:7-22

DOI: $\underline{10.1159 / 000207490}$
Received: May 19, 2008

Accepted after revision: September 8, 2008

Published online: April 17, 2009

\section{Drugs, Biogenic Amine Targets and the Developing Brain}

\author{
Aliya L. Frederick $^{\mathrm{a}}$ Gregg D. Stanwood $^{\mathrm{b}, \mathrm{c}}$ \\ ${ }^{a}$ Neuroscience Graduate Program, ${ }^{\text {b }}$ Department of Pharmacology, and ${ }^{\mathrm{C}}$ Vanderbilt Kennedy Center for Research \\ on Human Development, Vanderbilt University, Nashville, Tenn., USA
}

\section{Key Words}

Dopamine $\cdot$ Serotonin $\cdot$ Norepinephrine $\cdot$ Cocaine $\cdot$

Amphetamine Prenatal cocaine $\cdot$ Postnatal development . Developmental neurotoxicity $\cdot$ Cognitive development

\begin{abstract}
Defects in the development of the brain have a profound impact on mature brain functions and underlying psychopathology. Classical neurotransmitters and neuromodulators, such as dopamine, serotonin, norepinephrine, acetylcholine, glutamate and GABA, have pleiotropic effects during brain development. In other words, these molecules produce multiple diverse effects to serve as regulators of distinct cellular functions at different times in neurodevelopment. These systems are impacted upon by abuse of a variety of illicit drugs, neurotherapeutics and environmental contaminants. In this review, we describe the impact of drugs and chemicals on brain formation and function in animal models and in human populations, highlighting sensitive periods and effects that may not emerge until later in life.
\end{abstract}

Copyright $\odot 2009$ S. Karger AG, Basel

\section{KARGER}

Fax +4161306 1234

E-Mail karger@karger.ch

www.karger.com
(C) 2009 S. Karger AG, Basel

Accessible online at: www.karger.com/dne

\section{Many Drugs of Abuse and Therapeutics Target Biogenic Amines}

Biogenic amines are a group of neurotransmitters derived by the enzymatic decarboxylation of naturally occurring amino acids. These transmitters include the catecholamines, dopamine and norepinephrine, as well serotonin and acetylcholine. Each of these neurotransmitters has characteristic properties of synthesis, packaging, release, targets, degradation and action that allow its characterization at the synapse.

Biogenic amines are implicated in a wide range of behaviors, cognitive functions and homeostatic functions in the mature central nervous system (CNS). However, these neuromodulators appear early during embryogenesis, well before the onset of synaptogenesis, suggesting that they also play important roles in brain development. It is therefore not surprising that alterations to these systems, either by pharmacological agents that affect synthesis or binding in the mature system, or developmentally due to toxic insults or genetic modifications, will have important consequences on the brain. In this review, we will particularly emphasize the role of the developing dopamine system, but also describe data implicating noradrenergic and serotonergic projections. For discussion of other neurotransmitter systems and drug targets during development, we refer the reader elsewhere

\footnotetext{
Gregg D. Stanwood, PhD

Vanderbilt Kennedy Center

23rd Ave South, 476 RRB

Nashville, TN 37232-6600 (USA)

Tel. +1 615936 3861, Fax +1 615936 2202, E-Mail gregg.stanwood@vanderbilt.edu
} 
[Slotkin, 1998; Francis et al., 1999; Olney et al., 2002; Abreu-Villaca et al., 2003; Herlenius and Lagercrantz, 2004; Rodier, 2004; Holmes et al., 2005].

\section{Dopamine}

Dopamine (DA) is widely distributed in the adult CNS and serves a variety of functions in the mature brain, including control of movement. DA is also involved in regulation of the endocrine, limbic and cardiovascular systems. DA abnormalities appear to contribute to many neurological and psychiatric disorders, including schizophrenia, Parkinson's disease, attention-deficit hyperactivity disorder and drug addiction [Kiyatkin, 1995; Goldman-Rakic, 1998; Nestler, 2001; Girault and Greengard, 2004; Arnsten and Li, 2005; Biederman and Faraone, 2005; Kalivas and Volkow, 2005]. Many drugs used for therapeutic purposes, such as antipsychotics, act directly on the DA system.

All the catecholamines, characterized by a benzene ring with 2 hydroxyl groups and attached amine group, are derived from the amino acid tyrosine. DA is synthesized from conversion of L-tyrosine into L-dopa by the rate-limiting enzyme tyrosine hydroxylase. Subsequent activity of DOPA decarboxylase results in conversion to dopamine. DA receptors are characterized by an extracellular N-terminus region, intracellular C-terminus region and 7 membrane-spanning regions. The receptors are coupled intracellularly to guanine nucleotide-binding proteins that induce intracellular signaling cascades to influence regulation of calcium and potassium channels on the postsynaptic membrane. There are 2 subfamilies of DA receptors based on their pharmacological profiles and sequence homology: $\mathrm{D}_{1}$-like receptors and $\mathrm{D}_{2}$ like receptors. $\mathrm{D}_{1}$-like receptors, including the $\mathrm{D}_{1}$ and $\mathrm{D}_{5}$ receptor subtypes, catalyze the synthesis of cyclic adenosine monophosphate (cAMP) from the action of adenylate cyclase on adenosine triphosphate. $\mathrm{D}_{2}$-like receptors, including the $D_{2}, D_{3}$ and $D_{4}$ receptor subtypes, inhibit cAMP synthesis [Kebabian and Calne, 1979; Missale et al., 1998]. Transmitter action is terminated by re-uptake into the presynaptic terminal by a high-affinity plasma membrane dopamine transporter and ezymatically degraded by monoamine oxidase or catechol- $o$-methyl transferase.

There are several major dopaminergic pathways. The nigrostriatal tract consists of dopaminergic neurons in the substantia nigra pars compacta that terminate in the striatum, a major DA-containing area of the brain. The striatum is a component of the extrapyramidal motor system, and plays an essential role in the coordination of locomotor activity. Degeneration of the neurons in the nigrostriatal pathway is the primary pathological finding in Parkinson's disease, resulting in characteristic motor dysfunction. DA is also believed to be involved with the limbic system, particularly in behaviors associated with motivation, reward (endogenous systems and drug abuse) and reinforcement. The mesolimbic and mesocortical pathways are 2 midbrain dopaminergic pathways implicated in these behaviors. Both pathways begin in the midbrain ventral tegmental area (VTA) and provide input to the nucleus accumbens and frontal cortex (both medial prefrontal and anterior cingulate), respectively [Olson et al., 1972]. In monkeys, it has also been observed that a subset of VTA neurons provide innervation to the caudate nucleus of the striatum; thus, implicating the striatum in the regulation of emotional behaviors in this species [Lynd-Balta and Haber, 1994a, b; Haber et al., 1995].

Tyrosine hydroxylase, the rate-limiting enzyme in DA synthesis and a useful marker for identifying DA neurons, is first apparent at embryonic days (ED) 12-13 of an approximate 21-day gestational period in the rat midbrain, and is present by ED 14 of an approximate 30-day gestational period in the rabbit. DA is also likely to have early biological activity in the primate brain. In the monkey, DA neurons of the substantia nigra /VTA are produced between ED 36 and ED 43 of a 165-day gestational period [Levitt and Rakic, 1982]. In humans, midbrain DA neurons appear during the first trimester in the second month of gestation [Olson and Seiger, 1972]. This input is thus already present in the cortex even while more superficial cortical layers (II-IV) are beginning to form, consistent with a morphogenic role of DA.

Axons of dopaminergic cells reach the cortex a few days after their initial detection in the midbrain, innervating the cortex in a bilaminar pattern with greatest input into layers II and/or III and V and/or VI depending upon the cortical region in the monkey. This stands in contrast with the innervation pattern in rodents, in which there is substantial innervation of layer I as well as overlap between thalamic and catecholamine neurons in layer IV [Levitt et al., 1984]. Limbic cortical regions, such as the anterior cingulate and medial prefrontal cingulate receive the densest dopaminergic innervation. The density of tyrosine hydroxylase-positive axons in the cortex increases gradually over development, then declines postnatally to reach adult levels during puberty. This protracted postnatal increase in dopamine content occurs over a time period during which a number of developmental milestones occur that may involve transmitter 
signaling, including obtaining competency on working memory tasks [Lambe et al., 2000].

Fluorescent histochemical analysis of DA afferents in the cortex shows regional differences in DA input that correspond well with the heterogeneous distribution of endogenous DA content assayed biochemically in the cortex [Brown et al., 1979; Reader et al., 1989a]. In the monkey, in addition to dense prefrontal DA innervation, there is also substantial DA input to the premotor and primary motor cortex, as well as the anterior regions of the superior and inferior gyri of the temporal lobe. Minimal contributions of DA afferents, however, are found in the parietal and occipital lobes across species [Levitt et al., 1984; Reader et al., 1989a]. The mechanisms responsible for the proper guidance of dopaminergic afferents from the midbrain to the cortex and the morphogenic properties of these afferents on cortical neurons are not well-understood, but netrins and ephrins have been implicated [Yue et al., 1999; Flores et al., 2005; Lin and Isacson, 2006].

Transcripts for the $\mathrm{D}_{1}, \mathrm{D}_{2}$ and $\mathrm{D}_{3}$ receptors can be detected in the striatum and cortex by ED 14 in the rat and by ED 12 in the mouse [Jung and Bennett 1996; Araki et al., 2007]. $D_{1}$ and $D_{2}$ receptors are measurable at these early prenatal time points, and increase in abundance throughout prenatal and early postnatal development to reach adult levels of expression between postnatal days (PD) 14 and 21 in rodents [Sales et al., 1989; Rao et al., 1991; Schambra et al., 1994; Caille et al., 1995]. In the monkey, DA receptors appear in target regions of DA input by the first quarter of gestation [Lidow et al., 1991; Lidow 1995a], and, in humans, DA receptor binding sites have been detected by week 12 of gestation [Aubert et al., 1997]. Therefore, in all species examined, DA receptors are present very early in prenatal development, consistent with a role for DA in regulating neuronal differentiation and circuit formation. DA receptors have characteristic laminar distribution in the cortex, as observed in the monkey, $\left[{ }^{3} \mathrm{H}\right] \mathrm{SCH} 23390$-labeled $\mathrm{D}_{1}$ receptors have a bilaminar distribution with the highest concentration in the supragranular layers of the cortex (I,II and IIIa) and deep layers $\mathrm{V}$ and $\mathrm{VI}$ with relatively few receptors in intermediate strata. $\left[{ }^{3} \mathrm{H}\right]$ raclopride-labeled $\mathrm{D}_{2}$ receptors, on the other hand, are most concentrated in layer V and exist in lower densities than $D_{1}$ receptors throughout the cortex [Goldman-Rakic et al., 1990; Lidow et al., 1991]. Dense DA innervation into the superficial layers of cortex may be a primate specialization as binding in these layers has not been observed in rodents. The anatomical distribution of cortical DA receptors is heterogeneous through-

Neurodevelopmental Effects of Drugs and Toxicants out various brain regions, and corresponds with concentration of DA fiber input and endogenous DA and metabolites.

The majority of work thus presented has been done in the rodent, although comparisons have been made between species with available data on nonhuman primates and humans when possible and less often with rabbits. The characterization of the DA system in rabbits validates it as a relevant animal model for study (details further on). Pharmacological agents used to characterize $\mathrm{D}_{1}$ receptors in the rat, nonhuman primate and humans have similarly been used in rabbits to characterize highaffinity receptors in the cortex and striatum with similar pharmacological profiles as described in the aforementioned species [Reader et al., 1989b]. Similarly, $\mathrm{D}_{2}$ receptors have been characterized in the rabbit striatum and cortex [Dewar et al., 1989]. In the rabbit CNS, high levels of DA content are present within the anterior cingulate, while other cortical areas such as the somatosensory cortex and visual cortex have low levels of endogenous content. The highest concentrations of DA, as similarly observed in other species studied, are in the neostriatum with no differences between lateral and medial caudate or putamen in the rabbit. Receptor densities are heterogeneous between brain regions with the highest concentrations of $D_{1}$ and $D_{2}$ receptors in the striatum. In the striatum, $\mathrm{D}_{2}$ receptors exist in a lateral to medial gradient in the caudate, findings consistent with observations in the rat. In the cortex, $D_{1}$ receptor density is significantly lower than in the striatum, but corresponds with areas of DA innervation. $\mathrm{D}_{2}$ receptor density is also heterogenous, and less than $\mathrm{D}_{1}$ receptor density in the cortex [Dewar et al., 1989; Dewar and Reader, 1989; Reader et al., 1989b].

In vitro studies have supported a role for DA as both a promoter and an inhibitor of neurite growth [Todd, 1992; Reinoso et al., 1996; Song et al., 2002; Stanwood and Levitt, 2007]. The actions of DA on outgrowth are modified by the complement of receptors that are activated, and as a function of the neuronal cell type being modulated. For example, in cortical neurons, selective $\mathrm{D}_{1}$ receptor activation decreases neurite outgrowth in a dose-dependent manner, whereas $\mathrm{D}_{2}$ receptor activation increases outgrowth. In striatal neurons, however, these effects are reversed, with $D_{1}$ receptor activation serving to promote neuronal differentiation and process outgrowth. DA signaling also appears to be involved in prenatal neurogenesis itself within the neuroepithelial precursors of the striatum and cerebral cortex, via influences on cell cycle length [Ohtani et al., 2003; Zhang et al., 2005]. The phenotypic differentiation and migration of inhibitory 
GABAergic interneurons may also be modulated by dopaminergic stimulation [Crandall et al., 2007]. Studies from our laboratory and others investigating the effects of prenatal cocaine exposure suggest that modification of $D A D_{1}$ receptor signaling during a sensitive period of prenatal development induces permanent effects on circuit formation and function (see below). Recent data also suggests that transient overexpression of the $\mathrm{D}_{2}$ receptor in the developing striatum can cause life-long changes in the activity of $D_{1}$ receptor systems in the prefrontal cortex [Kellendonk et al., 2006]. Finally, DA-dependent processes also alter postnatal development of brain circuits, especially during the periods of synaptic maturation and refinement.

\section{Norepinephrine or Noradrenaline}

Norepinephrine (NE) is synthesized and released by adrenergic axon terminals in both the CNS and the sympathetic division of the autonomic nervous system. In the CNS, the cell bodies of NE neurons are concentrated in the brainstem, particularly in the locus coeruleus of the dorsal pons where they are involved in diffuse projections to the neocortex [Segal et al., 1973; Levitt and Moore, 1978; Lindvall et al., 1978; Levitt et al., 1984]. NE is involved in mediating attention, anxiety, arousal, feeding behaviors, and learning and memory.

NE neurons are born at a relatively early time in the CNS of monkeys during the first quarter of gestation, approximately ED 30 for neurons in the medial locus coeruleus and ED 32/ED 33 for those situated more laterally. In rats, fluorescently labeled neurons are observed in the nucleus early in gestation, at approximately ED 13 [Olson and Seiger, 1972; Lauder and Bloom, 1974b]. The majority of NE axon terminals ascend to the forebrain in the dorsal tegmental bundle, dessucating almost immediately or more rostrally to join the ascending medial forebrain bundle. Fluorescence histochemistry suggests that developing axons enter the neocortex across multiple cortical layers; however, as the cortex matures, NE afferent input is most concentrated in a bilaminar pattern, predominantly in layers II and/or III (superficial) and V and/or VI (deep). There is heterogenerity in density of NE input between cortical regions with the somatosensory cortex receiving the densest NE innervation. NE fibers are also found intermingled with DA neurons in areas of the prefrontal cortex, as well anterior parts of the superior and inferior temporal gyri. NE innervation is sparsest in posterior parietal areas and occipital lobes including visual cortex [Levitt et al., 1984; Reader et al., 1989a]. These synapses mature during early postnatal life and the adult pattern of innervation is obtained by the end of the first postnatal week in rodents [Lauder and Bloom, 1975; Levitt and Moore, 1979]. In primates, there is a considerably longer maturation process postnatally as the first postnatal week in rodents is equivalent to the third trimester in primates.

NE synthesis requires DA as a precursor substrate. DA is trafficked by vesicular transport into adrenergic terminals where it is converted to NE by the enzymatic activity of DA $\beta$-hydroxylase [Segal et al., 1973]. Receptors sensitive to NE are divided into 2 classes, $\alpha$ - and $\beta$-adrenergic receptors, based upon the physiological response to catecholamines. The classes are further divided into subtypes, of which there exists $\alpha_{1}, \alpha_{2}, \beta_{1}$ and $\beta_{2}$ based on pharmacological profiles. In rodents, $\alpha_{1}$ - and $\alpha_{2}$-adrenoreceptor expression can be detected 1 day after birth by specific radioligand binding. Receptor binding increases with age, reaching a peak between PD 18 and 21 before declining to reach adult levels after the fourth postnatal week [Morris et al., 1980]. A similar trend in ontogeny is apparent with $\beta$-adrenergic receptors, with these receptors not being detected before PD 7 [Harden et al., 1977; Pittman et al., 1980].

$\left[{ }^{3} \mathrm{H}\right]$ clonidine labeled $\alpha_{2}$-receptors in the monkey are predominately found in the superficial layers of the cortex, with a descending concentration gradient from layers I to VI. Similarly, the density of $\left[{ }^{3} \mathrm{H}\right]$ prazosin-labeled $\alpha_{1}{ }^{-}$ receptors decreases from layers I to IV; however, there is a slight increase in receptor concentration in the deeper cortical layers. $\beta_{1}$ and $\beta_{2}$ receptors are most concentrated in the intermediate layers of the cortex [Goldman-Rakic et al., 1990]. Species differences exist between primates and rodents in stratification of receptor density. In the rat, the highest concentration of $\alpha_{1}$-receptors are found in layers III and IV, and $\beta$ receptors are homogenously distributed.

Both types of receptors alter the postsynaptic membrane potential by acting upon potassium and calcium channels. Like DA, NE is terminated by reuptake into the presynaptic terminal by a high-affinity transporter, where it is enzymatically degraded or inactivated by monoamine oxidase.

\section{Serotonin (5-Hydroxytryptamine)}

Serotonin (5-HT) is a well-known modulator of a variety of cognitive and behavioral functions, including sleep, sexual urge, anxiety, appetite, temperature regulation, learning and memory, and mood. As such, 5-HT imbalances are implicated in a variety of disorders such as depression, anxiety disorders and aggression [Olivier 
et al., 1995; Lucki 1998; Gingrich and Hen, 2001]. 5-HT also exerts influence during specific critical periods during early development. Accumulated evidence indicates that 5-HT plays a role in many developmental processes, including neurogenesis; neuronal migration and differentiation; synaptogenesis; and craniofacial, cardiac and limb development, prior to assuming is role as a neurotransmitter in the mature brain [Whitaker-Azmitia, 2001; Gaspar et al., 2003; Persico et al., 2006]. 5-HT also plays crucial roles in thalamocortical patterning [Lebrand et al., 1996; Rebsam et al., 2002; Bonnin et al., 2007].

Serotonergic neurons are among the earliest neurons to be generated during development of the brain. In the monkey, serotonergic neurogenesis in the brainstem raphe nuclei is evident by the end of the first month of gestation in 2 distinct phases. Neurons in rostral raphe nuclei are generated between ED 28 and 35 with a peak genesis around ED 30. Caudal raphe nuclei are generated somewhat later with peak neurogenesis between ED 38 and 40 [Levitt and Rakic, 1982]. In rodents, 5-HT neurons are evident in the midbrain by ED 12 [Lauder and Bloom, 1974a], and by the fifth week of gestation in humans [Olson and Seiger, 1972; Sundstrom et al., 1993; Lambe et al., 2000]. One day after their generation, serotonergic neurons in the raphe can synthesize and release 5 -HT from their growing axonal processes [Lidov and Molliver, 1982; Lambe et al., 2000]. Serotonergic terminals are found broadly throughout the forebrain, including the thalamus and cortex. In the cortex, serotonergic input is greatest in visual and somatosensory cortical areas, and less in prefrontal and temporal cortical regions. 5-HT levels increase prenatally through the early postnatal years before declining to reach adult levels [WhitakerAzmitia, 2001].

Numerous 5-HT receptors exist and are grouped into 7 different families based on molecular cloning. Additional receptor motifs are created through the acts of mRNA splicing and editing events. Each receptor subtype possesses distinct cellular and/or regional distributions, pharmacological profiles and signal transduction systems. Most 5-HT receptors are heterotrimeric G protein-coupled receptors that activate calcium and potassium channels through intracellular signaling cascades. 5$\mathrm{HT}_{4}, 5-\mathrm{HT}_{6}$ and $5-\mathrm{HT}_{7}$ receptors couple to the stimulatory $\mathrm{G}_{\mathrm{s}} \alpha$ protein to increase activity of adenylate cyclase. $5-\mathrm{HT}_{3}$ receptors, however, are ligand-gated ion channels [Hartig 1994; Jackson and Yakel, 1995].

5-HT receptors are also expressed early in prenatal development [Hellendall et al., 1993; Bonnin et al., 2006].
For example, 5- $\mathrm{HT}_{2}$ receptor immunoreactivity is initially apparent in the cortex between ED 19 and PD 0 in rodents. After birth, there is a rapid increase in expression levels in layers II-VI followed by gradual decline to adult levels beginning around the second postnatal week [Morilak and Ciaranello, 1993]. In the adult, $5-\mathrm{HT}_{2}$ receptors are concentrated in the intermediate strata III and IV of the cortex. Receptor localization is consistent between rodents, monkey and humans [Goldman-Rakic et al., 1990; Morilak and Ciaranello, 1993]. Similarly, the same developmental trend is observed for expression of $5-\mathrm{HT}_{1}$ receptors. At birth, the percentage of receptors expressed varies among brain regions with densities ranging from 5 to $50 \%$ of adult levels. There is then a transient increase in expression levels followed by a decrease to adult levels during the first postnatal month [Pranzatelli, 1993]. In the adult monkey, $5-\mathrm{HT}_{1}$ receptors are found in highest concentrations in the superficial layers of the cortex [Goldman-Rakic et al., 1990]. 5- $\mathrm{HT}_{1}$ receptor localization is consistent between monkey and human, while in the rat receptor density is greatest in layer V [Hoyer et al., 1986].

The synaptic effects of 5-HT are terminated by reuptake of the neurotransmitter into the presynaptic nerve terminals through a high-affinity 5-HT transporter (SERT). After reuptake, 5-HT is subsequently degraded by the enzymatic catabolic activity of monoamine oxidase. A number of neurotherapeutic drugs used in the treatment of depression and anxiety disorders act by inhibiting reuptake of the transmitter by SERT [Blakely et al., 1994; Jayanthi and Ramamoorthy, 2005; White et al., 2005].

\section{Developmental Cocaine Exposure Alters Neurobehavioral Development}

The primary pharmacological sites of action of cocaine and other psychostimulants in the brain are the high-affinity transporters for DA, 5-HT and NE. Cocaine binds to these transporter proteins and blocks the reuptake of the neurotransmitters; thus, prolonging their time in the extracellular space. This permits the monoamine to bind to its receptor proteins for more sustained periods, resulting in excessive activation of these receptors, particularly those located extrasynaptically. Cocaine, a drug of abuse in adolescents and adults, produces a host of neuroadaptations in the brain of the user which are associated with addiction [Hyman and Malen$\mathrm{ka}, 2001$ ], and can potently modulate monoaminergic 
systems during prenatal development if the drug is used during pregnancy [Malanga and Kosofsky, 2003; Stanwood and Levitt, 2004].

Clinical reports on the impact of prenatal cocaine exposure have been diverse, as some suggest gross physical malformations, others observe specific deficits in cognitive and emotional development, and yet others indicate no detectable effects. The variable outcomes are at least in part the result of important covariates such as the timing and amount of cocaine use during pregnancy, polydrug use, and the quality of pre- and postnatal care [Karmel and Gardner, 1996; Richardson et al., 1996; Gingras and O'Donnell, 1998; Dow-Edwards et al., 1999; Mayes et al., 2003; Singer et al., 2004]. In particular, prenatal cocaine exposure can have long-lasting negative effects on cognitive and attention systems. For example, prenatal cocaine exposure predicts poorer perceptual reasoning IQ compared to nonexposed counterparts [Singer et al., 2008], impairments in procedural learning [Mayes et al., 2007], increased behavioral problems in school [Bada et al., 2007] and increased risk of oppositional defiant disorder and attention-deficit hyperactivity disorder [Linares et al., 2006].

Different animal models, designed to mimic human drug use during gestation, confirm that prenatal cocaine exposure results in specific and long-lasting behavioral, cellular and molecular changes [Mayes, 2002; Lidow, 2003; Harvey, 2004; Stanwood and Levitt, 2004]. However, the extent and nature of the cellular alterations vary across model systems. Deficits range from alterations in basic processes of neocortical development that result in altered cell production, migration and genetic regulation [Gressens et al., 1992; Lidow, 1995b; Lidow and Song, 2001; Crandall et al., 2004; Ren et al., 2004; Guerriero et al., 2005; Lee et al., 2008; Novikova et al., 2008], to more subtle changes in cellular morphology and molecular signaling cascades within DA-rich regions of the cerebral cortex [Jones et al., 1996; Jones et al., 2000; Stanwood et al., 2001a; Stanwood and Levitt, 2003; Stanwood and Levitt, 2007]. In contrast to the cellular effects, consistent behavioral changes including deficits in attention tasks, emotional reactivity, and the reinforcing properties of drugs of abuse that correspond with the human clinical literature are observed in a variety of animal models of prenatal cocaine exposure [Morrow et al., 2002; Rocha et al., 2002; Gabriel et al., 2003; Stanwood and Levitt, 2003; Thompson et al., 2005b; Malanga et al., 2008].

One unique animal model of prenatal cocaine exposure, to study the mechanisms underlying the complex long-term adaptive changes and the functional outcomes of in utero cocaine exposure, utilizes a low-dose regimen of intravenous prenatal cocaine exposure in the rabbit, which was initially selected for ease of intravenous administration. Furthermore, the pharmacokinetic profile of intravenous cocaine in the rabbit [Parlaman et al., 2007] closely models what is seen when human users abuse cocaine [Evans et al., 1996; Jenkins et al., 2002]. A number of studies have established that the prenatal dosing is not generally teratogenic, nor does it impact basic developmental parameters such as kit mortality, litter size, sex or growth rates [Wang et al., 1995b; Jones et al., 1996; Wang et al., 1996; Murphy et al., 1997]. However, through control of length of drug exposure, age at drug exposure, and dosing, we have delineated a critical window of time (ED 16-25) during which exposure to cocaine affects behavior, morphology and cellular composition [Stanwood et al., 2001a; Stanwood et al., 2001b; Stanwood and Levitt, 2003; Thompson et al., 2005b]. This window of time corresponds to the emergence of pre- and postsynaptic components of the DA system in the cerebral cortex [Stanwood et al., 2001a].

Neuroanatomical and molecular analyses in this model have delineated a number of highly specific changes in DA-rich cortical areas, including changes in GABA content, calcium binding protein expression and morphological changes in pyramidal cells [Murphy et al., 1997; Jones et al., 2000; Stanwood and Levitt, 2001; Stanwood et al., 2001b; Stanwood et al., 2006; Stanwood and Levitt, 2007]. The specific neuronal morphology alterations include a $40-50 \%$ increase in pyramidal neuron apical dendrite length within DA-rich cortical areas [Jones et al., 2000], which are involved in cognition and executive functioning tasks, including attention [Goldman-Rakic, 1996; Collette and Van der Linden, 2002; Elliott, 2003; Elston, 2003; Clark et al., 2004].

Consistent with the regional selectivity in the anatomical findings, extensive behavioral characterization of rabbits following in utero exposure to cocaine suggest that the behaviors disrupted appear to be limited to those mediated via select DA-rich cortical and subcortical regions [Romano and Harvey, 1996; Simansky et al., 1998; Gabriel et al., 2003; Stanwood and Levitt, 2003; Thompson et al., 2005b]. For example, these animals exhibit decreases in spontaneous alternation as measured by the Y-maze following prenatal cocaine exposure [Thompson et al., 2005b]. This decrease in attention is not accompanied by changes in open-field behavior or 2-object recognition. Additionally, offspring exposed to prenatal cocaine show a decreased number of head bobs, a measure of stereotypy, following a single injection of amphet- 
amine, and display a blunted preference for cocaine in a conditioned place preference paradigm [Stanwood and Levitt, 2003; Thompson et al., 2005a].

Molecular analyses have determined that the DA $D_{1}$ receptor exhibits permanently reduced coupling to its cognate $G$ protein, $G_{s} \alpha$, following prenatal cocaine exposure [Wang et al., 1995a; Friedman et al., 1996; Jones et al., 2000]. This reduction in coupling is a result of DA $\mathrm{D}_{1}$ receptor remaining internalized and not trafficking properly to the cell membrane where it would then interact with $\mathrm{G}_{\mathrm{s}} \alpha$ [Stanwood and Levitt, 2007]. Adult rabbits exposed to cocaine prenatally also exhibit greatly reduced psychostimulant-induced stereotypies, consistent with diminished $D_{1}$ receptor signaling [Simansky and Kachelries, 1996; Stanwood and Levitt, 2003]. It is important to emphasize that other $\mathrm{G}_{\mathrm{s}} \alpha$-coupled receptor signaling is not altered, nor is $\mathrm{D}_{2}$ coupling altered in the DA-rich brain regions [Wang et al., 1995a; Friedman et al., 1996]. This selective reduced coupling of the $\mathrm{D}_{1}$ receptor has been implicated in the cellular, morphological and behavioral changes observed following prenatal cocaine exposure in our model. Additional evidence to support a role for altered $D_{1}$ receptor signaling at the cellular level comes from our recent study of the $\mathrm{D}_{1}$ receptor knockout mouse, which exhibits similar cellular and morphological changes to the prenatal cocaine exposed rabbits [Stanwood et al., 2005].

\section{Effects of Developmental Amphetamine/ Methamphetamine Exposure}

Although amphetamine and methamphetamine use and abuse has been present for decades, there has been comparatively (to cocaine) little clinical and basic research on its effects on brain development. Reports have only recently emerged from a large prospective study [Smith et al., 2006; Smith et al., 2008]. Early clinical reports emphasized increases in premature delivery, placental abruption, cardiac defects and fetal distress [for reviews, see Plessinger, 1998; Smith et al., 2006]. In utero methamphetamine-exposed children are at high risk of growth impairment [Smith et al., 2003] and are 3.5-fold more likely to be smaller than average for gestational age [Smith et al., 2006], perhaps not surprising given the anorectic effects of the drug.

Even fewer studies have examined neurobehavioral outcomes specifically. In neonates, methamphetamine exposure is associated with lower arousal, more lethargy and increased physiological stress [Smith et al., 2008]. In a small retrospective study, significant deficits in visuomotor integration, attention and memory have been observed and linked to smaller volumes of the putamen, globus pallidus and hippocampus [Chang et al., 2004]. Imaging studies also point to alterations in striatal energy metabolism in children exposed gestationally [Smith et al., 2001; Chang et al., 2007]. It will clearly be important to continue to follow these children for impairments of this nature as they develop and enter schools.

Animal models utilizing a wide variety of species, doses and timing of exposure have been used to investigate the consequences of prenatal exposure on development. At high doses, methamphetamine induces prominent teratogenic effects on the neonate [Nora et al., 1965; Kasirsky, 1971]. A very good animal model of third trimester exposure has been developed by Vorhees et al. [2000, 2007], who inject neonatal rat pups during the ages spanning PD 11-21 with multiple spaced injections. This exposure paradigm produces selective effects on spatial learning and memory [Vorhees et al., 2000; Williams et al., 2003; Vorhees et al., 2007], and both transient and permanent effects in stress hormones and brain biogenic amines [Williams et al., 2005; Schaefer et al., 2008]. Interestingly, neonatal methamphetamine exposure does not alter striatal DA levels [Schaefer et al., 2008], very unlike its effect in adult animals, where it produces long lasting decreases in DA [Cappon et al., 2000].

Other groups have reported changes in the structure and myelination of the optic nerve [Melo et al., 2006, 2008], altered seizure susceptibility [Slamberova et al., 2008] and reduced spontaneous motor activity [Cho et al., 1991; Weissman and Caldecott-Hazard, 1993] following prenatal methamphetamine exposure. Long-lasting changes in the function of the NE [Nasif et al., 1999] and 5-HT [Tavares et al., 1996] systems have also been described following in utero amphetamine exposure.

\section{Effects of Developmental MDMA Exposure}

3,4-Methylenedioxymethamphetamine (MDMA, ecstasy) is a derivative of methamphetamine acting primarily on the 5-HT system to increase 5-HT release. In adults, MDMA produces enhanced mood, euphoria, heightened sensory awareness and sympathetic arousal, including tachycardia and hyperthermia [Lyles and Cadet, 2003]. At high doses, MDMA is capable of neurotoxicity. MDMA also passes through the placental barrier to enter into the fetal circulation [Campbell et al., 2006], suggesting that MDMA use during pregnancy is capable of inducing ef- 
fects in the offspring. 5-HT has well-documented effects on early development of the brain and other organs [Cases et al., 1996; Bonnin et al., 2007; Cote et al., 2007], raising concerns about deleterious effects of MDMA use during pregnancy.

In fact, a preliminary study of prenatal MDMA-exposed children demonstrated increased risks of cardiovascular and musculoskeletal abnormalities following exposure during the first trimester [McElhatton et al., 1999]. Prenatal exposure in animal models and culture systems also suggest deleterious effects of MDMA on the development of dopaminergic and serotonergic neurons [Won et al., 2002; Koprich et al., 2003; Galineau et al., 2005] and increases in locomotor activity in adolescent offspring [Koprich et al., 2003]. Third trimester equivalent exposure in rats also leads to learning difficulties [Broening et al., 2001; Williams et al., 2003]; similar to the effects of the 5-HT releaser D-fenfluramine [Morford et al., 2002]. These effects may be due to increased sensitivity of 5- $\mathrm{HT}_{1 \mathrm{~A}}$ receptors [Crawford et al., 2006], and were recently reviewed in exquisite detail [Piper, 2007; Skelton et al., 2008].

\section{Potential Developmental Impact of Therapeutic Medications}

Biogenic amine systems are also targeted by psychoactive medications, including antidepressant and antipsychotic drugs. To test for a possible developmental role of the 5-HT system in establishing anxiety circuitry, Hen and colleagues generated a conditional knockout mouse that allowed for temporally restricted rescue of postsynaptic $5-\mathrm{HT}_{1 \mathrm{~A}}$ receptors in the cerebral cortex and hippocampus [Gross et al., 2002]. Using this strategy, they demonstrated that initiating expression of the receptor after PD 21 resulted in increased anxiety levels identical to constitutive $5-\mathrm{HT}_{1 \mathrm{~A}}$ receptor knockout animals. Conversely, earlier expression of the $5-\mathrm{HT}_{1 \mathrm{~A}}$ receptor, during the first 3 postnatal weeks, produced mice with anxiety levels that were indistinguishable from wild-type animals, even if the receptor was turned off in adulthood. Administration of the selective 5-HT reuptake inhibitor fluoxetine from PD 4 to 21 also leads to permanent changes in anxiety behavior [Ansorge et al., 2004]. These findings indicate that normal 5-HT activity during early postnatal development in the rodent is crucial to the establishment of normal anxiety-modulating circuits in the brain, and that both genetic and environmental factors are capable of influencing these circuits.
Consistent with the rodent models, data from human studies suggest that baseline anxiety levels are influenced early in life. By 2 years of age, most children have established cohesive patterns of response to novel environments, as measured by behavioral inhibition. These measures appear to be stable over many years [Hirshfeld et al., 1992; Rosenbaum et al., 1993; Schwartz et al., 1999; see also Degnan and Fox, 2007], and can predict one's future risk of anxiety disorders [Kagan and Snidman, 1999; Kagan et al., 2007]. Not surprisingly, polymorphisms in 5HT system-related genes have all been associated with anxiety- and depression-related symptoms [Albert and Lemonde, 2004; Kim et al., 2006; Walderhaug et al., 2007; Dannlowski et al., 2008; Murphy and Lesch, 2008]. Many prominent psychotherapeutics target the 5-HT system, and are utilized for depression and anxiety among pregnant and nursing mothers. Published literature to date suggests only modest alterations in neonatal outcome [Pearson et al., 2007; Andrade et al., 2008; Maschi et al., 2008; Oberlander et al., 2008], but further study of the neurobehavioral consequences of antidepressant exposure on the developing fetus and infant are clearly needed. Possible long-lasting changes in drug-seeking behavior following maternal 5-HT reuptake inhibitor exposure have also been recently suggested [Forcelli and Heinrichs, 2008].

Antipsychotic drugs are another group of therapeutics needed by some pregnant women and young people suffering from schizophrenia and other psychotic illnesses. Again, however, these drugs have potent effects on the development of aminergic systems, especially on DA receptors [Rosengarten and Friedhoff, 1979; Moran-Gates et al., 2006]. These drugs can also produce long-lasting changes in neurochemistry, brain architecture, and behavior [Scalzo and Spear, 1985; Scalzo et al., 1993; Singh and Singh, 2001; Rosengarten and Quartermain, 2002; Singh and Singh, 2002; Wang et al., 2006].

Another intriguing and unexpected example has come from developmental studies of terbutaline, a $\beta$-adrenoceptor agonist used to arrest preterm labor. However, the drug also crosses the placenta and blood-brain barrier. Early postnatal exposure to terbutaline in rats, a period corresponding to the third trimester in humans, produces long-lasting alterations in NE innervation and receptor expression in multiple brain regions [Slotkin et al., 1990; Slotkin et al., 2001; Rhodes et al., 2004; Aldridge et al., 2005; Slotkin and Seidler, 2007a], as well as increasing the toxic consequences of subsequent pesticide exposure (see 'Environmental Agents/Toxins') [Meyer et al., 2005]. Increased microglial activation, behavioral abnormali- 
ties and alterations in 5-HT systems have also been reported [Aldridge et al., 2005; Zerrate et al., 2007]. In humans, it has been suggested that terbutaline treatment during pregnancy may lead to an increased incidence of autism spectrum disorder in offspring [Connors et al., 2005]; similarly gain-of-function polymorphisms in the $\beta_{2}$-adrenergic receptor which produce receptors that are resilient to desensitization have been associated with autism [Connors et al., 2005; Cheslack-Postava et al., 2007].

\section{Environmental Agents/Toxins}

Thousands of new chemicals are produced each year, about $25 \%$ of them may be neurotoxic, but only about $10 \%$ of them will ever be tested for such activity [Connors et al., 2008]. Long-lasting neurodevelopmental effects on biogenic amine systems and their targets have been described for some of these chemicals and environmental contaminants, including lead [Szczerbak et al., 2007; Nowak et al., 2008], polychlorinated biphenyls [Bushnell et al., 2002; Kuchiiwa et al., 2002], polybrominated diphenyl ethers [Dingemans et al., 2007; Llansola et al., 2007; Alm et al., 2008; Gee and Moser, 2008], pyrethroids [Nasuti et al., 2007], organic solvents [Hougaard et al., 1999; Gospe and Zhou, 2000; Bowen and Hannigan, 2006], and synthetic estrogens such as bisphenol-A [Suzuki et al., 2003; Laviola et al., 2005; Miyagawa et al., 2007]. These 'nondrug' environmental factors can interact with developmental drug exposures and/or genetic factors to produce complex effects on brain formation and function, often at concentration levels that appear to be harmless for adults. For example, perinatal exposure to bisphenol-A can produce longlasting potentiation of $\mathrm{D}_{1} \mathrm{DA}$ receptor function, supersensitivity to methamphetamine and decreases in the expression of genes crucial for DA neuron development and survival, such as sonic hedgehog and glial-derived neurotrophic factor [Suzuki et al., 2003; Suzuki et al., 2005; Miyagawa et al., 2007]. Even artificial food colors and preservatives such as sodium benzoate appear to contribute to hyperactivity in children [McCann et al., 2007]. It is well beyond the scope of this review to describe all of these compounds in detail [for more detailed reviews, see Costa et al., 2004; Rodier, 2004; Slotkin, 2004; Bowen and Hannigan, 2006; Johansson et al., 2007; Moser, 2007], but we will very briefly discuss 2 classes of compounds with likely effects on the development of brain biogenic amines and their targets.

Neurodevelopmental Effects of Drugs and Toxicants
Organophosphate pesticides inhibit cholinesterases, and produce cholinergic overstimulation. In addition, developmental exposure to the compounds, such as chlorpyrifos, produces effects on serotonergic synaptic function [Slotkin and Seidler, 2007b; Moreno et al., 2008; Roegge et al., 2008]. Most exposure occurs through dietary intake [Lu et al., 2008]. Importantly, many of these effects on 5-HT and 5-HT-mediated behaviors, such as the development of emotional systems, occur at doses below the threshold for cholinesterase inhibition [Levin et al., 2002; Slotkin et al., 2006; Roegge et al., 2008]. Pre- and perinatal exposure also produces long-lasting changes in components of brain DA systems, and even increases cell loss at later developmental times following exposure to dopaminergic neurotoxins used to model Parkinson's disease [Richardson et al., 2006]. Recent studies identifying functional polymorphisms affecting chlorpyrifos metabolism [Berkowitz et al., 2004] and documenting decreases in cognitive development in children exposed to chlorpyrifos during gestation suggests that this is a very significant human health problem [Rauh et al., 2006; Engel et al., 2007].

Lastly, we describe data regarding manganese, a common naturally occurring heavy metal and essential nutrient. Manganese is crucial for maintaining the proper function and regulation of many biological processes, but is also used in numerous industries including welding, mining and formulating gasoline additives. Manganese is readily transported into the brain, either as a free ion species or as a nonspecific protein-bound species [Aschner and Gannon, 1994]. Chronic manganese overexposure results in the onset of a very specific neurological phenotype, known as manganism, which presents with motor symptoms resembling those of Parkinson's disease [Lee, 2000; Normandin et al., 2002; Guilarte et al., 2006; Aschner et al., 2007]. Similar symptoms have also been described in adults and children receiving prolonged total parenteral nutrition [Kafritsa et al., 1998; Nagatomo et al., 1999; Hsieh et al., 2007], which contains high amounts of manganese [Erikson et al., 2007].

Emerging data from both animal and human studies suggest a potent effect of developmental manganese exposure on brain development [Erikson et al., 2007; Ljung and Vahter, 2007]. For example, manganese exposure during pregnancy and/or early postnatal life produces alterations in locomotor activity, brain monoamine levels, oxidative stress and brain morphology [Pappas et al., 1997; Tran et al., 2002; Erikson et al., 2006; Reichel et al., 2006]. In children, preliminary studies have associated elevated manganese content in drinking water with de-

Dev Neurosci 2009;31:7-22 
creased cognitive and attentional functions [Wasserman et al., 2006; Bouchard et al., 2007]. Increased prenatal manganese exposure has also been linked to childhood behavioral disinhibition [Ericson et al., 2007]. Moreover, iron deficiency can enhance brain manganese accumulation, even in the absence of excess manganese in the environment, and produce long-lasting changes in metal concentrations and transporters in the brain [Garcia et al., 2007]. These data warrant a reassessment of guideline values for acceptable manganese levels and much more detailed investigations into the risks of environmental manganese exposure.

\section{Conclusions}

The mammalian brain develops over a protracted period of time. Neurodevelopment is affected by both genetic and environmental influences, within the context of evolving time. Environmental influences can have effects on brain architecture both prenatally, within the mother's womb, and by the physical and chemical environment experienced after birth. Compounds which affect the construction of brain circuits include legal and illicit psychoactive drugs, used either medicinally or recreationally, as well as environmental toxicants and natural contaminants. Biogenic amine systems may be particularly sensitive to such modulation. Resulting disruptions in brain development sometimes do not emerge until later in life, and may be produced at dose levels that are relatively harmless for adults. This makes the study of these long-term impacts very challenging, but also very crucial. Scientists must continue to inform the public and policy makers of these complex and important issues.

\section{Acknowledgments}

Support was received from NICHD core grant P30-HD15052 (G.D.S.), the Vanderbilt Kennedy Center (G.D.S.) and the Vanderbilt Medical Scientist Training Program (A.L.F.). We thank Drs. Pat Levitt and Barbara Thompson for helpful discussions and productive collaborations on the prenatal cocaine model.

\section{References}

Abreu-Villaca Y, Seidler FJ, Tate CA, Slotkin TA Araki KY, Sims JR, Bhide PG (2007): Dopamine (2003): Nicotine is a neurotoxin in the adolescent brain: critical periods, patterns of exposure, regional selectivity, and dose thresholds for macromolecular alterations. Brain Res 979:114-128.

-Albert PR, Lemonde S (2004): 5-HT1A receptors, gene repression, and depression: guilt by association. Neuroscientist 10:575-593.

-Aldridge JE, Meyer A, Seidler FJ, Slotkin TA (2005): Developmental exposure to terbutaline and chlorpyrifos: pharmacotherapy of preterm labor and an environmental neurotoxicant converge on serotonergic systems in neonatal rat brain regions. Toxicol Appl Pharmacol 203:132-144.

Alm H, Kultima K, Scholz B, Nilsson A, Andren PE, Fex-Svenningsen A, Dencker L, Stigson M (2008): Exposure to brominated flame retardant PBDE-99 affects cytoskeletal protein expression in the neonatal mouse cerebral cortex. Neurotoxicology 29:628-637.

Andrade SE, Raebel MA, Brown J, Lane K, Livingston J, Boudreau D, Rolnick SJ, Roblin D, Smith DH, Willy ME, Staffa JA, Platt R (2008): Use of antidepressant medications during pregnancy: a multisite study. Am J Obstet Gynecol 198:194 e191-e195.

-Ansorge MS, Zhou M, Lira A, Hen R, Gingrich JA (2004): Early-life blockade of the 5-HT transporter alters emotional behavior in adult mice. Science 306:879-881. receptor $\mathrm{mRNA}$ and protein expression in the mouse corpus striatum and cerebral cortex during pre- and postnatal development. Brain Res 1156:31-45.

Arnsten AF, Li BM (2005): Neurobiology of executive functions: catecholamine influences on prefrontal cortical functions. Biol Psychiatry 57:1377-1384.

Aschner M, Gannon M (1994): Manganese (Mn) transport across the rat blood-brain barrier: saturable and transferrin-dependent transport mechanisms. Brain Res Bull 33:345349.

Aschner M, Guilarte TR, Schneider JS, Zheng W (2007): Manganese: recent advances in understanding its transport and neurotoxicity. Toxicol Appl Pharmacol 221:131-147.

-Aubert I, Brana C, Pellevoisin C, Giros B, Caille I, Carles D, Vital C, Bloch B (1997): Molecular anatomy of the development of the human substantia nigra. J Comp Neurol 379:72-87.

Bada HS, Das A, Bauer CR, Shankaran S, Lester B, LaGasse L, Hammond J, Wright LL, Higgins R (2007): Impact of prenatal cocaine exposure on child behavior problems through school age. Pediatrics 119:e348-e359.

-Berkowitz GS, Wetmur JG, Birman-Deych E, Obel J, Lapinski RH, Godbold JH, Holzman IR, Wolff MS (2004): In utero pesticide exposure, maternal paraoxonase activity, and head circumference. Environ Health Perspect 112:388-391.
Biederman J, Faraone SV (2005): Attention-deficit hyperactivity disorder. Lancet 366:237248.

Blakely RD, De Felice LJ, Hartzell HC (1994) Molecular physiology of norepinephrine and serotonin transporters. J Exp Biol 196:263281.

Bonnin A, Peng W, Hewlett W, Levitt P (2006): Expression mapping of $5-\mathrm{HT}_{1}$ serotonin receptor subtypes during fetal and early postnatal mouse forebrain development. Neuroscience 141:781-794.

Bonnin A, Torii M, Wang L, Rakic P, Levitt P (2007): Serotonin modulates the response of embryonic thalamocortical axons to netrin1. Nat Neurosci 10:588-597.

Bouchard M, Laforest F, Vandelac L, Bellinger D, Mergler D (2007): Hair manganese and hyperactive behaviors: pilot study of school-age children exposed through tap water. Environ Health Perspect 115:122-127.

Bowen SE, Hannigan JH (2006): Developmental toxicity of prenatal exposure to toluene. AAPS J 8:E419-E424.

Broening HW, Morford LL, Inman-Wood SL, Fukumura M, Vorhees CV (2001): 3,4methylenedioxymethamphetamine (ecstasy)-induced learning and memory impairments depend on the age of exposure during early development. J Neurosci 21:3228-3235. 
Brown RM, Crane AM, Goldman PS (1979): Regional distribution of monoamines in the cerebral cortex and subcortical structures of the rhesus monkey: concentrations and in vivo synthesis rates. Brain Res 168:133-150.

- Bushnell PJ, Moser VC, MacPhail RC, Oshiro WM, Derr-Yellin EC, Phillips PM, Kodavanti PR (2002): Neurobehavioral assessments of rats perinatally exposed to a commercial mixture of polychlorinated biphenyls. Toxicol Sci 68:109-120.

-Caille I, Dumartin B, Le Moine C, Begueret J, Bloch B (1995): Ontogeny of the $D_{1}$ dopamine receptor in the rat striatonigral system: an immunohistochemical study. Eur J Neurosci 7:714-722.

-Campbell NG, Koprich JB, Kanaan NM, Lipton JW (2006): MDMA administration to pregnant Sprague-Dawley rats results in its passage to the fetal compartment. Neurotoxicol Teratol 28:459-465.

-Cappon GD, Pu C, Vorhees CV (2000): Timecourse of methamphetamine-induced neurotoxicity in rat caudate-putamen after single-dose treatment. Brain Res 863:106-111.

-Cases O, Vitalis T, Seif I, De Maeyer E, Sotelo C, Gaspar P (1996): Lack of barrels in the somatosensory cortex of monoamine oxidase A-deficient mice: role of a serotonin excess during the critical period. Neuron 16:297307.

-Chang L, Alicata D, Ernst T, Volkow N (2007): Structural and metabolic brain changes in the striatum associated with methamphetamine abuse. Addiction 102(suppl 1):1632.

-Chang L, Smith LM, LoPresti C, Yonekura ML, Kuo J, Walot I, Ernst T (2004): Smaller subcortical volumes and cognitive deficits in children with prenatal methamphetamine exposure. Psychiatry Res 132:95-106.

-Cheslack-Postava K, Fallin MD, Avramopoulos D, Connors SL, Zimmerman AW, Eberhart CG, Newschaffer CJ (2007): Beta2-adrenergic receptor gene variants and risk for autism in the AGRE cohort. Mol Psychiatry 12:283291.

-Cho DH, Lyu HM, Lee HB, Kim PY, Chin K (1991): Behavioral teratogenicity of methamphetamine. J Toxicol Sci 16(suppl 1):37-49.

Clark L, Cools R, Robbins TW (2004): The neuropsychology of ventral prefrontal cortex: decision-making and reversal learning. Brain Cogn 55:41-53.

Collette F, Van der Linden M (2002): Brain imaging of the central executive component of working memory. Neurosci Biobehav Rev 26:105-125.

-Connors SL, Crowell DE, Eberhart CG, Copeland J, Newschaffer CJ, Spence SJ, Zimmerman AW (2005): Beta2-adrenergic receptor activation and genetic polymorphisms in autism: data from dizygotic twins. J Child Neurol 20:876-884.
Connors SL, Levitt P, Matthews SG, Slotkin TA, Johnston MV, Kinney HC, Johnson WG, Dailey RM, Zimmerman AW (2008): Fetal mechanisms in neurodevelopmental disorders. Pediatr Neurol 38:163-176.

- Costa LG, Aschner M, Vitalone A, Syversen T, Soldin OP (2004): Developmental neuropathology of environmental agents. Annu Rev Pharmacol Toxicol 44:87-110.

Cote F, Fligny C, Bayard E, Launay JM, Gershon MD, Mallet J, Vodjdani G (2007): Maternal serotonin is crucial for murine embryonic development. Proc Natl Acad Sci USA 104: 329-334.

Crandall JE, Hackett HE, Tobet SA, Kosofsky BE, Bhide PG (2004): Cocaine exposure decreases GABA neuron migration from the ganglionic eminence to the cerebral cortex in embryonic mice. Cereb Cortex 14:665-675.

-Crandall JE, McCarthy DM, Araki KY, Sims JR, Ren JQ, Bhide PG (2007): Dopamine receptor activation modulates GABA neuron migration from the basal forebrain to the cerebral cortex. J Neurosci 27:3813-3822.

Crawford CA, Williams MT, Kohutek JL, Choi FY, Yoshida ST, McDougall SA, Vorhees CV (2006): Neonatal 3,4-methylenedioxymethamphetamine (MDMA) exposure alters neuronal protein kinase A activity, serotonin and dopamine content, and [35S]GTPgammaS binding in adult rats. Brain Res 1077:178-186.

Dannlowski U, Ohrmann P, Bauer J, Deckert J, Hohoff C, Kugel H, Arolt V, Heindel W, Kersting A, Baune BT, Suslow T (2008): 5-HTTLPR biases amygdala activity in response to masked facial expressions in major depression. Neuropsychopharmacology 33:418424.

Degnan KA, Fox NA (2007): Behavioral inhibition and anxiety disorders: multiple levels of a resilience process. Dev Psychopathol 19: 729-746.

Dewar KM, Montreuil B, Grondin L, Reader TA (1989): Dopamine $D_{2}$ receptors labeled with $[3 \mathrm{H}]$ raclopride in rat and rabbit brains: equilibrium binding, kinetics, distribution and selectivity. J Pharmacol Exp Ther 250:696706.

Dewar KM, Reader TA (1989): Distribution of dopamine $D_{1}$ and $D_{2}$ receptors in rabbit cortical areas, hippocampus, and neostriatum in relation to dopamine contents. Synapse 4: 378-386.

Dingemans MM, Ramakers GM, Gardoni F, van Kleef RG, Bergman A, Di Luca M, van den Berg M, Westerink RH, Vijverberg HP (2007): Neonatal exposure to brominated flame retardant BDE-47 reduces long-term potentiation and postsynaptic protein levels in mouse hippocampus. Environ Health Perspect 115:865-870.

Dow-Edwards D, Mayes L, Spear L, Hurd Y (1999): Cocaine and development: clinical, behavioral, and neurobiological perspectives - a symposium report. Neurotoxicol Teratol 21:481-490.
Elliott R (2003): Executive functions and their disorders. Br Med Bull 65:49-59.

Elston GN (2003): Cortex, cognition and the cell: new insights into the pyramidal neuron and prefrontal function. Cereb Cortex 13:11241138.

Engel SM, Berkowitz GS, Barr DB, Teitelbaum SL, Siskind J, Meisel SJ, Wetmur JG, Wolff MS (2007): Prenatal organophosphate metabolite and organochlorine levels and performance on the Brazelton Neonatal Behavioral Assessment Scale in a multiethnic pregnancy cohort. Am J Epidemiol 165: 1397-1404

Ericson JE, Crinella FM, Clarke-Stewart KA, Allhusen VD, Chan T, Robertson RT (2007): Prenatal manganese levels linked to childhood behavioral disinhibition. Neurotoxicol Teratol 29:181-187.

Erikson KM, Dorman DC, Fitsanakis V, Lash LH, Aschner M (2006): Alterations of oxidative stress biomarkers due to in utero and neonatal exposures of airborne manganese. Biol Trace Elem Res 111:199-215.

- Erikson KM, Thompson K, Aschner J, Aschner M (2007): Manganese neurotoxicity: a focus on the neonate. Pharmacol Ther 113:369-377.

Evans SM, Cone EJ, Henningfield JE (1996): Arterial and venous cocaine plasma concentrations in humans: relationship to route of administration, cardiovascular effects and subjective effects. J Pharmacol Exp Ther 279: 1345-1356.

- Flores C, Manitt C, Rodaros D, Thompson KM, Rajabi H, Luk KC, Tritsch NX, Sadikot AF, Stewart J, Kennedy TE (2005): Netrin receptor deficient mice exhibit functional reorganization of dopaminergic systems and do not sensitize to amphetamine. Mol Psychiatry 10:606-612.

Forcelli PA, Heinrichs SC (2008): Teratogenic effects of maternal antidepressant exposure on neural substrates of drug-seeking behavior in offspring. Addict Biol 13:52-62.

Francis DD, Caldji C, Champagne F, Plotsky PM, Meaney MJ (1999): The role of corticotropinreleasing factor - norepinephrine systems in mediating the effects of early experience on the development of behavioral and endocrine responses to stress. Biol Psychiatry 46: 1153-1166.

Friedman E, Yadin E, Wang HY (1996): Effect of prenatal cocaine on dopamine receptor-G protein coupling in mesocortical regions of the rabbit brain. Neuroscience 70:739-747.

Gabriel M, Taylor C, Burhans L (2003): In utero cocaine, discriminative avoidance learning with low-salient stimuli and learning-related neuronal activity in rabbits (Oryctolagus $\mathrm{cu}$ niculus). Behav Neurosci 117:912-926.

Galineau L, Belzung C, Kodas E, Bodard S, Guilloteau D, Chalon S (2005): Prenatal 3,4methylenedioxymethamphetamine (ecstasy) exposure induces long-term alterations in the dopaminergic and serotonergic functions in the rat. Brain Res Dev Brain Res 154: 165-176. 
-Garcia SJ, Gellein K, Syversen T, Aschner M (2007): Iron deficient and manganese supplemented diets alter metals and transporters in the developing rat brain. Toxicol Sci 95: 205-214.

-Gaspar P, Cases O, Maroteaux L (2003): The developmental role of serotonin: news from mouse molecular genetics. Nat Rev Neurosci 4:1002-1012.

-Gee JR, Moser VC (2008): Acute postnatal exposure to brominated diphenylether 47 delays neuromotor ontogeny and alters motor activity in mice. Neurotoxicol Teratol 30:7987.

Gingras JL, O’Donnell KJ (1998): State control in the substance-exposed fetus. I. The fetal neurobehavioral profile: an assessment of fetal state, arousal, and regulation competency. Ann NY Acad Sci 846:262-276.

Gingrich JA, Hen R (2001): Dissecting the role of the serotonin system in neuropsychiatric disorders using knockout mice. Psychopharmacology (Berl) 155:1-10.

Girault JA, Greengard P (2004): The neurobiology of dopamine signaling. Arch Neurol 61: 641-644.

Goldman-Rakic PS (1996): The prefrontal landscape: implications of functional architecture for understanding human mentation and the central executive. Philo Trans R Soc Lond B Biol Sci 351:1445-1453.

Goldman-Rakic PS (1998): The cortical dopamine system: role in memory and cognition. Adv Pharmacol 42:707-711.

-Goldman-Rakic PS, Lidow MS, Gallager DW (1990): Overlap of dopaminergic, adrenergic, and serotoninergic receptors and complementarity of their subtypes in primate prefrontal cortex. J Neurosci 10:2125-2138.

-Gospe SM Jr, Zhou SS (2000): Prenatal exposure to toluene results in abnormal neurogenesis and migration in rat somatosensory cortex. Pediatr Res 47:362-368.

-Gressens P, Kosofsky BE, Evrard P (1992): Cocaine-induced disturbances of corticogenesis in the developing murine brain. Neurosci Lett 140:113-116.

-Gross C, Zhuang X, Stark K, Ramboz S, Oosting R, Kirby L, Santarelli L, Beck S, Hen R (2002): Serotonin $_{1 \mathrm{~A}}$ receptor acts during development to establish normal anxiety-like behaviour in the adult. Nature 416:396-400.

-Guerriero RM, Rajadhyaksha A, Crozatier C, Giros B, Nosten-Bertrand M, Kosofsky BE (2005): Augmented constitutive CREB expression in the nucleus accumbens and striatum may contribute to the altered behavioral response to cocaine of adult mice exposed to cocaine in utero. Dev Neurosci 27:235-248.

- Guilarte TR, McGlothan JL, Degaonkar M, Chen MK, Barker PB, Syversen T, Schneider JS (2006): Evidence for cortical dysfunction and widespread manganese accumulation in the nonhuman primate brain following chronic manganese exposure: ${ }^{1} \mathrm{H}-\mathrm{MRS}$ and MRI study. Toxicol Sci 94:351-358.
Haber SN, Ryoo H, Cox C, Lu W (1995): Subsets of midbrain dopaminergic neurons in monkeys are distinguished by different levels of mRNA for the dopamine transporter: comparison with the mRNA for the $\mathrm{D}_{2}$ receptor, tyrosine hydroxylase and calbindin immunoreactivity. J Comp Neurol 362:400-410.

-Harden TK, Wolfe BB, Sporn JR, Perkins JP, Molinoff PB (1977): Ontogeny of beta-adrenergic receptors in rat cerebral cortex. Brain Res 125:99-108.

Hartig PR (1994): Molecular pharmacology of serotonin receptors. EXS 71:93-102.

Harvey JA (2004): Cocaine effects on the developing brain: current status. Neurosci Biobehav Rev 27:751-764.

Hellendall RP, Schambra UB, Liu JP, Lauder JM (1993): Prenatal expression of 5- $\mathrm{HT}_{1 \mathrm{C}}$ and 5 $\mathrm{HT}_{2}$ receptors in the rat central nervous system. Exp Neurol 120:186-201.

Herlenius E, Lagercrantz H (2004): Development of neurotransmitter systems during critical periods. Exp Neurol 190(suppl 1):S8-S21.

Hirshfeld DR, Rosenbaum JF, Biederman J, Bolduc EA, Faraone SV, Snidman N, Reznick JS, Kagan J (1992): Stable behavioral inhibition and its association with anxiety disorder. J Am Acad Child Adolesc Psychiatry 31:103-111.

Dolmes A, le Guisquet AM, Vogel E, Millstein RA, Leman S, Belzung C (2005): Early life genetic, epigenetic and environmental factors shaping emotionality in rodents. Neurosci Biobehav Rev 29:1335-1346.

- Hougaard KS, Hass U, Lund SP, Simonsen L (1999): Effects of prenatal exposure to toluene on postnatal development and behavior in rats. Neurotoxicol Teratol 21:241-250.

- Hoyer D, Pazos A, Probst A, Palacios JM (1986): Serotonin receptors in the human brain. I. Characterization and autoradiographic localization of $5-\mathrm{HT}_{1 \mathrm{~A}}$ recognition sites: apparent absence of $5-\mathrm{HT}_{1 \mathrm{~B}}$ recognition sites. Brain Res 376:85-96.

Hsieh CT, Liang JS, Peng SS, Lee WT (2007): Seizure associated with total parenteral nutrition-related hypermanganesemia. Pediatr Neurol 36:181-183.

Hyman SE, Malenka RC (2001): Addiction and the brain: the neurobiology of compulsion and its persistence. Nat Rev Neurosci 2:695703.

Jackson MB, Yakel JL (1995): The 5- $\mathrm{HT}_{3}$ receptor channel. Annu Rev Physiol 57:447-468.

Jayanthi LD, Ramamoorthy S (2005): Regulation of monoamine transporters: influence of psychostimulants and therapeutic antidepressants. AAPS J 7:E728-E738.

Jenkins AJ, Keenan RM, Henningfield JE, Cone EJ (2002): Correlation between pharmacological effects and plasma cocaine concentrations after smoked administration. J Anal Toxicol 26:382-392.

Johansson C, Castoldi AF, Onishchenko N, Manzo L, Vahter M, Ceccatelli S (2007): Neurobehavioural and molecular changes induced by methylmercury exposure during development. Neurotox Res 11:241-260.
Jones L, Fischer I, Levitt P (1996): Nonuniform alteration of dendritic development in the cerebral cortex following prenatal cocaine exposure. Cereb Cortex 6:431-445.

Jones LB, Stanwood GD, Reinoso BS, Washington RA, Wang HY, Friedman E, Levitt P (2000): In utero cocaine-induced dysfunction of dopamine $\mathrm{D}_{1}$ receptor signaling and abnormal differentiation of cerebral cortical neurons. J Neurosci 20:4606-4614.

-Jung AB, Bennett JP Jr (1996): Development of striatal dopaminergic function. I. Pre- and postnatal development of mRNAs and binding sites for striatal $\mathrm{D}_{1}\left(\mathrm{D}_{1 \mathrm{a}}\right)$ and $\mathrm{D}_{2}\left(\mathrm{D}_{2 \mathrm{a}}\right)$ receptors. Brain Res Dev Brain Res 94:109-120.

Kafritsa Y, Fell J, Long S, Bynevelt M, Taylor W, Milla P (1998): Long-term outcome of brain manganese deposition in patients on home parenteral nutrition. Arch Dis Child 79:263265.

Kagan J, Snidman N (1999): Early childhood predictors of adult anxiety disorders. Biol Psychiatry 46:1536-1541.

Kagan J, Snidman N, Kahn V, Towsley S (2007): The preservation of two infant temperaments into adolescence. Monogr Soc Res Child Dev 72:1-75, vii, discussion 76-91.

Kalivas PW, Volkow ND (2005): The neural basis of addiction: a pathology of motivation and choice. Am J Psychiatry 162:1403-1413.

Karmel BZ, Gardner JM (1996): Prenatal cocaine exposure effects on arousal-modulated attention during the neonatal period. Dev Psychobiol 29:463-480.

Kasirsky G (1971): Teratogenic effects of methamphetamine in mice and rabbits. J Am Osteopath Assoc 70:1119-1120.

Kebabian JW, Calne DB (1979): Multiple receptors for dopamine. Nature 277:93-96.

Kellendonk C, Simpson EH, Polan HJ, Malleret G, Vronskaya S, Winiger V, Moore H, Kandel ER (2006): Transient and selective overexpression of dopamine $\mathrm{D}_{2}$ receptors in the striatum causes persistent abnormalities in prefrontal cortex functioning. Neuron 49:603-615.

Kim H, Lim SW, Kim S, Kim JW, Chang YH, Carroll BJ, Kim DK (2006): Monoamine transporter gene polymorphisms and antidepressant response in Koreans with late-life depression. JAMA 296:1609-1618.

Kiyatkin EA (1995): Functional significance of mesolimbic dopamine. Neurosci Biobehav Rev 19:573-598.

Koprich JB, Chen EY, Kanaan NM, Campbell NG, Kordower JH, Lipton JW (2003): Prenatal 3,4methylenedioxymethamphetamine (ecstasy) alters exploratory behavior, reduces monoamine metabolism, and increases forebrain tyrosine hydroxylase fiber density of juvenile rats. Neurotoxicol Teratol 25:509-517.

Kuchiiwa S, Cheng SB, Nagatomo I, Akasaki Y, Uchida M, Tominaga M, Hashiguchi W, Kuchiiwa T (2002): In utero and lactational exposure to 2,3,7,8-tetrachlorodibenzo-pdioxin decreases serotonin-immunoreactive neurons in raphe nuclei of male mouse offspring. Neurosci Lett 317:73-76. 
-Lambe EK, Krimer LS, Goldman-Rakic PS (2000): Differential postnatal development of catecholamine and serotonin inputs to identified neurons in prefrontal cortex of rhesus monkey. J Neurosci 20:8780-8787.

Lauder J, Bloom F (1974a): Ontogeny of monoamine neurons in the locus coeruleus, raphe nuclei, and substantia nigra of the rat. I. Cell differentiation. J Comp Neurol 155:469-482.

Lauder JM, Bloom FE (1974b): Ontogeny of monoamine neurons in the locus coeruleus, raphe nuclei and substantia nigra of the rat. I. Cell differentiation. J Comp Neurol 155: 469-481.

Lauder JM, Bloom FE (1975): Ontogeny of monoamine neurons in the locus coeruleus, raphe nuclei and substantia nigra of the rat. II. Synaptogenesis. J Comp Neurol 163:251-264.

- Laviola G, Gioiosa L, Adriani W, Palanza P (2005): D-amphetamine-related reinforcing effects are reduced in mice exposed prenatally to estrogenic endocrine disruptors. Brain Res Bull 65:235-240.

-Lebrand C, Cases O, Adelbrecht C, Doye A, Alvarez C, El Mestikawy S, Seif I, Gaspar P (1996): Transient uptake and storage of serotonin in developing thalamic neurons. Neuron 17:823-835.

- Lee CT, Chen J, Hayashi T, Tsai SY, Sanchez JF, Errico SL, Amable R, Su TP, Lowe RH, Huestis MA, Shen J, Becker KG, Geller HM, Freed WJ (2008): A mechanism for the inhibition of neural progenitor cell proliferation by cocaine. PLoS Med 5:e117.

Lee JW (2000): Manganese intoxication. Arch Neurol 57:597-599.

-Levin ED, Addy N, Baruah A, Elias A, Christopher NC, Seidler FJ, Slotkin TA (2002): Prenatal chlorpyrifos exposure in rats causes persistent behavioral alterations. Neurotoxicol Teratol 24:733-741.

Levitt P, Moore RY (1978): Noradrenaline neuron innervation of the neocortex in the rat. Brain Res 139:219-231.

Levitt P, Moore RY (1979): Development of the noradrenergic innervation of neocortex. Brain Res 162:243-259.

Levitt P, Rakic P (1982): The time of genesis, embryonic origin and differentiation of the brain stem monoamine neurons in the rhesus monkey. Brain Res 256:35-57.

Levitt P, Rakic P, Goldman-Rakic P (1984): Region-specific distribution of catecholamine afferents in primate cerebral cortex: a fluorescence histochemical analysis. J Comp Neurol 227:23-36.

Lidov HG, Molliver ME (1982): Immunohistochemical study of the development of serotonergic neurons in the rat CNS. Brain Res Bull 9:559-604.

- Lidow MS (1995a): $\mathrm{D}_{1}$ - and $\mathrm{D}_{2}$ dopaminergic receptors in the developing cerebral cortex of macaque monkey: a film autoradiographic study. Neuroscience 65:439-452.

Lidow MS (1995b): Prenatal cocaine exposure adversely affects development of the primate cerebral cortex. Synapse 21:332-341.
Lidow MS (2003): Consequences of prenatal cocaine exposure in nonhuman primates. Brain Res Dev Brain Res 147:23-36.

Lidow MS, Goldman-Rakic PS, Gallager DW, Rakic P (1991): Distribution of dopaminergic receptors in the primate cerebral cortex: quantitative autoradiographic analysis using $[3 \mathrm{H}]$ raclopride, $[3 \mathrm{H}]$ spiperone and [3H]SCH23390. Neuroscience 40:657-671.

Lidow MS, Song ZM (2001): Primates exposed to cocaine in utero display reduced density and number of cerebral cortical neurons. J Comp Neurol 435:263-275

Lin L, Isacson O (2006): Axonal growth regulation of fetal and embryonic stem cell-derived dopaminergic neurons by Netrin-1 and Slits. Stem Cells 24:2504-2513.

- Linares TJ, Singer LT, Kirchner HL, Short EJ, Min MO, Hussey P, Minnes S (2006): Mental health outcomes of cocaine-exposed children at 6 years of age. J Pediatr Psychol 31: 85-97.

Lindvall O, Bjorkland A, Divac I (1978): Organization of catecholamine neurons projecting to the frontal cortex of the rat. Brain Res 142: $1-24$.

Ljung K, Vahter M (2007): Time to re-evaluate the guideline value for manganese in drinking water? Environ Health Perspect 115: $1533-1538$

Llansola M, Erceg S, Monfort P, Montoliu C, Felipo V (2007): Prenatal exposure to polybrominated diphenylether 99 enhances the function of the glutamate-nitric oxidecGMP pathway in brain in vivo and in cultured neurons. Eur J Neurosci 25:373-379.

Lu C, Barr DB, Pearson MA, Waller LA (2008): Dietary intake and its contribution to longitudinal organophosphorus pesticide exposure in urban/suburban children. Environ Health Perspect 116:537-542.

Lucki I (1998): The spectrum of behaviors influenced by serotonin. Biol Psychiatry 44:151162.

Lyles J, Cadet JL (2003): Methylenedioxymethamphetamine (MDMA, ecstasy) neurotoxicity: cellular and molecular mechanisms. Brain Res Brain Res Rev 42:155-168.

Lynd-Balta E, Haber SN (1994a): The organization of midbrain projections to the striatum in the primate: sensorimotor-related striatum versus ventral striatum. Neuroscience 59:625-640.

Lynd-Balta E, Haber SN (1994b): The organization of midbrain projections to the ventral striatum in the primate. Neuroscience 59: 609-623.

Malanga CJ, Kosofsky BE (2003): Does drug abuse beget drug abuse? Behavioral analysis of addiction liability in animal models of prenatal drug exposure. Brain Res Dev Brain Res 147:47-57.

Malanga CJ, Riday TT, Carlezon WA Jr, Kosofsky BE (2008): Prenatal exposure to cocaine increases the rewarding potency of cocaine and selective dopaminergic agonists in adult mice. Biol Psychiatry 63:214-221.
Maschi S, Clavenna A, Campi R, Schiavetti B, Bernat M, Bonati M (2008): Neonatal outcome following pregnancy exposure to antidepressants: a prospective controlled cohort study. BJOG 115:283-289.

-Mayes L, Snyder PJ, Langlois E, Hunter N (2007): Visuospatial working memory in schoolaged children exposed in utero to cocaine. Child Neuropsychol 13:205-218.

Mayes LC (2002): A behavioral teratogenic model of the impact of prenatal cocaine exposure on arousal regulatory systems. Neurotoxicol Teratol 24:385-395.

- Mayes LC, Cicchetti D, Acharyya S, Zhang H (2003): Developmental trajectories of cocaine-and-other-drug-exposed and non-cocaine-exposed children. J Dev Behav Pediatr 24:323-335.

- McCann D, Barrett A, Cooper A, Crumpler D, Dalen L, Grimshaw K, Kitchin E, Lok K, Porteous L, Prince E, Sonuga-Barke E, Warner JO, Stevenson J (2007): Food additives and hyperactive behaviour in 3-year-old and 8/9year-old children in the community: a randomised, double-blinded, placebo-controlled trial. Lancet 370:1560-1567.

- McElhatton PR, Bateman DN, Evans C, Pughe KR, Thomas SH (1999): Congenital anomalies after prenatal ecstasy exposure. Lancet 354:1441-1442.

Melo P, Moreno VZ, Vazquez SP, Pinazo-Duran MD, Tavares MA (2006): Myelination changes in the rat optic nerve after prenatal exposure to methamphetamine. Brain Res 1106:21-29.

-Melo P, Pinazo-Duran MD, Salgado-Borges J, Tavares MA (2008): Correlation of axon size and myelin occupancy in rats prenatally exposed to methamphetamine. Brain Res 1222: 61-68.

- Meyer A, Seidler FJ, Aldridge JE, Slotkin TA (2005): Developmental exposure to terbutaline alters cell signaling in mature rat brain regions and augments the effects of subsequent neonatal exposure to the organophosphorus insecticide chlorpyrifos. Toxicol Appl Pharmacol 203:154-166.

- Missale C, Nash SR, Robinson SW, Jaber M Caron MG (1998): Dopamine receptors: from structure to function. Physiol Rev 78: 189-225.

- Miyagawa K, Narita M, Narita M, Niikura K, Akama H, Tsurukawa Y, Suzuki T (2007): Changes in central dopaminergic systems with the expression of Shh or GDNF in mice perinatally exposed to bisphenol-A. Nihon Shinkei Seishin Yakurigaku Zasshi 27:69-75.

-Moran-Gates T, Gan L, Park YS, Zhang K, Baldessarini RJ, Tarazi FI (2006): Repeated antipsychotic drug exposure in developing rats: dopamine receptor effects. Synapse 59: 92-100.

- Moreno M, Canadas F, Cardona D, Sunol C, Campa L, Sanchez-Amate MC, Flores P, Sanchez-Santed F (2008): Long-term monoamine changes in the striatum and nucleus accumbens after acute chlorpyrifos exposure. Toxicol Lett 176:162-167. 
Morford LL, Inman-Wood SL, Gudelsky GA, Nowak P, Szczerbak G, Nitka D, Kostrzewa RM, Williams MT, Vorhees CV (2002): Impaired spatial and sequential learning in rats treated neonatally with D-fenfluramine. Eur J Neurosci 16:491-500.

Morilak DA, Ciaranello RD (1993): Ontogeny of 5-hydroxytryptamine2 receptor immunoreactivity in the developing rat brain. Neuroscience 55:869-880.

- Morris MJ, Dausse JP, Devynck MA, Meyer P (1980): Ontogeny of alpha 1 and alpha 2-adrenoceptors in rat brain. Brain Res 190:268271.

Morrow BA, Elsworth JD, Roth RH (2002): Prenatal cocaine exposure disrupts non-spatial, short-term memory in adolescent and adult male rats. Behav Brain Res 129:217-223.

Moser VC (2007): Animal models of chronic pesticide neurotoxicity. Hum Exp Toxicol 26:321-331.

Murphy DL, Lesch KP (2008): Targeting the murine serotonin transporter: insights into human neurobiology. Nat Rev Neurosci 9:8596.

-Murphy EH, Fischer I, Friedman E, Grayson D, Jones L, Levitt P, O’Brien-Jenkins A, Wang HY, Wang XH (1997): Cocaine administration in pregnant rabbits alters cortical structure and function in their progeny in the absence of maternal seizures. Exp Brain Res 114:433-441.

-Nagatomo S, Umehara F, Hanada K, Nobuhara Y, Takenaga S, Arimura K, Osame M (1999): Manganese intoxication during total parenteral nutrition: report of two cases and review of the literature. J Neurol Sci 162:102105.

- Nasif FJ, Cuadra GR, Ramirez OA (1999): Permanent alteration of central noradrenergic system by prenatally administered amphetamine. Brain Res Dev Brain Res 112:181188.

Nasuti C, Gabbianelli R, Falcioni ML, Di Stefano A, Sozio P, Cantalamessa F (2007): Dopaminergic system modulation, behavioral changes, and oxidative stress after neonatal administration of pyrethroids. Toxicology 229: 194-205.

Nestler EJ (2001): Neurobiology: total recall the memory of addiction. Science 292:22662267.

Nora JJ, Trasler DG, Fraser FC (1965): Malformations in mice induced by dexamphetamine sulphate. Lancet ii:1021-1022.

-Normandin L, Panisset M, Zayed J (2002): Manganese neurotoxicity: behavioral, pathological, and biochemical effects following various routes of exposure. Rev Environ Health 17:189-217.

- Novikova SI, He F, Bai J, Cutrufello NJ, Lidow MS, Undieh AS (2008): Maternal cocaine administration in mice alters DNA methylation and gene expression in hippocampal neurons of neonatal and prepubertal offspring. PLoS ONE 3:e1919. Sitkiewicz T, Brus R (2008): Effect of prenatal lead exposure on nigrostriatal neurotransmission and hydroxyl radical formation in rat neostriatum: Dopaminergic-nitrergic interaction. Toxicology 246:83-89.

- Oberlander TF, Bonaguro RJ, Misri S, Papsdorf M, Ross CJ, Simpson EM (2008): Infant serotonin transporter (SLC6A4) promoter genotype is associated with adverse neonatal outcomes after prenatal exposure to serotonin reuptake inhibitor medications. Mol Psychiatry 13:65-73.

Ohtani N, Goto T, Waeber C, Bhide PG (2003): Dopamine modulates cell cycle in the lateral ganglionic eminence. J Neurosci 23:28402850.

Olivier B, Mos J, van Oorschot R, Hen R (1995): Serotonin receptors and animal models of aggressive behavior. Pharmacopsychiatry 28(suppl 2):80-90.

Olney JW, Wozniak DF, Farber NB, JevtovicTodorovic V, Bittigau P, Ikonomidou C (2002): The enigma of fetal alcohol neurotoxicity. Ann Med 34:109-119.

Olson L, Seiger A (1972): Early prenatal ontogeny of central monoamine neurons in the rat: fluorescence histochemical observations. Z Anat Entwicklungsgesch 137:301-316.

Olson L, Seiger A, Fuxe K (1972): Heterogeneity of striatal and limbic dopamine innervation: highly fluorescent islands in developing and adult rats. Brain Res 44:283-288.

Pappas BA, Zhang D, Davidson CM, Crowder T, Park GA, Fortin T (1997): Perinatal manganese exposure: behavioral, neurochemical, and histopathological effects in the rat. Neurotoxicol Teratol 19:17-25.

Parlaman JP, Thompson BL, Levitt P, Stanwood GD (2007): Pharmacokinetic profile of cocaine following intravenous administration in the female rabbit. Eur J Pharmacol 563: 124-129.

Pearson KH, Nonacs RM, Viguera AC, Heller VL, Petrillo LF, Brandes M, Hennen J, Cohen LS (2007): Birth outcomes following prenatal exposure to antidepressants. J Clin Psychiatry 68:1284-1289.

Persico AM, Di Pino G, Levitt P (2006): Multiple receptors mediate the trophic effects of serotonin on ventroposterior thalamic neurons in vitro. Brain Res 1095:17-25.

- Piper BJ (2007): A developmental comparison of the neurobehavioral effects of ecstasy (MDMA). Neurotoxicol Teratol 29:288-300.

- Pittman RN, Minneman KP, Molinoff PB (1980): Ontogeny of beta 1 - and beta 2-adrenergic receptors in rat cerebellum and cerebral cortex. Brain Res 188:357-368.

Plessinger MA (1998): Prenatal exposure to amphetamines: risks and adverse outcomes in pregnancy. Obstet Gynecol Clin North Am 25:119-138.

Pranzatelli MR (1993): Regional differences in the ontogeny of 5-hydroxytryptamine-1C binding sites in rat brain and spinal cord. Neurosci Lett 149:9-11.
Rao PA, Molinoff PB, Joyce JN (1991): Ontogeny of dopamine $\mathrm{D}_{1}$ and $\mathrm{D}_{2}$ receptor subtypes in rat basal ganglia: a quantitative autoradiographic study. Dev Brain Res 60:161-177.

-Rauh VA, Garfinkel R, Perera FP, Andrews HF, Hoepner L, Barr DB, Whitehead R, Tang D, Whyatt RW (2006): Impact of prenatal chlorpyrifos exposure on neurodevelopment in the first 3 years of life among inner-city children. Pediatrics 118:e1845-e1859.

Reader TA, Dewar KM, Grondin L (1989a): Distribution of monoamines and metabolites in rabbit neostriatum, hippocampus and cortex. Brain Res Bull 23:237-247.

Reader TA, Grondin L, Montreuil B, Dewar KM (1989b): Dopamine $D_{1}$ receptors labelled with [3H]SCH23390 in rabbit cerebral cortex and neostriatum: equilibrium binding, kinetics and selectivity. Naunyn Schmiedebergs Arch Pharmacol 340:617-625.

-Rebsam A, Seif I, Gaspar P (2002): Refinement of thalamocortical arbors and emergence of barrel domains in the primary somatosensory cortex: a study of normal and monoamine oxidase a knock-out mice. J Neurosci 22:8541-8552.

-Reichel CM, Wacan JJ, Farley CM, Stanley BJ, Crawford CA, McDougall SA (2006): Postnatal manganese exposure attenuates cocaine-induced locomotor activity and reduces dopamine transporters in adult male rats. Neurotoxicol Teratol 28:323-332.

-Reinoso BS, Undie AS, Levitt P (1996): Dopamine receptors mediate differential morphological effects on cerebral cortical neurons in vitro. J Neurosci Res 43:439-453.

-Ren JQ, Malanga CJ, Tabit E, Kosofsky BE (2004): Neuropathological consequences of prenatal cocaine exposure in the mouse. Int J Dev Neurosci 22:309-320.

Rhodes MC, Seidler FJ, Abdel-Rahman A, Tate CA, Nyska A, Rincavage HL, Slotkin TA (2004): Terbutaline is a developmental neurotoxicant: effects on neuroproteins and morphology in cerebellum, hippocampus, and somatosensory cortex. J Pharmacol Exp Ther 308:529-537.

-Richardson GA, Conroy ML, Day NL (1996): Prenatal cocaine exposure: effects on the development of school-age children. Neurotoxicol Teratol 18:627-634.

Richardson JR, Caudle WM, Wang M, Dean ED, Pennell KD, Miller GW (2006): Developmental exposure to the pesticide dieldrin alters the dopamine system and increases neurotoxicity in an animal model of Parkinson's disease. FASEB J 20:1695-1697.

Rocha BA, Mead AN, Kosofsky BE (2002): Increased vulnerability to self-administer cocaine in mice prenatally exposed to cocaine. Psychopharmacology (Berl) 163:221-229.

Rodier PM (2004): Environmental causes of central nervous system maldevelopment. Pediatrics 113:1076-1083. 
- Roegge CS, Timofeeva OA, Seidler FJ, Slotkin TA, Levin ED (2008): Developmental diazinon neurotoxicity in rats: later effects on emotional response. Brain Res Bull 75:166172.

Romano AG, Harvey JA (1996): Elicitation and modification of the rabbit's nictitating membrane reflex following prenatal exposure to cocaine. Pharmacol Biochem Behav 53:857862.

- Rosenbaum JF, Biederman J, Bolduc-Murphy EA, Faraone SV, Chaloff J, Hirshfeld DR, Kagan J (1993): Behavioral inhibition in childhood: a risk factor for anxiety disorders. Harv Rev Psychiatry 1:2-16.

-Rosengarten H, Friedhoff AJ (1979): Enduring changes in dopamine receptor cells of pups from drug administration to pregnant and nursing rats. Science 203:1133-1135.

-Rosengarten H, Quartermain D (2002): Effect of prenatal administration of haloperidol, risperidone, quetiapine and olanzapine on spatial learning and retention in adult rats. Pharmacol Biochem Behav 72:575-579.

-Sales N, Martres MP, Bouthenet ML, Schwartz JC (1989): Ontogeny of dopaminergic D-2 receptors in the rat nervous system: characterization and detailed autoradiographic mapping with [125I]iodosulpride. Neuroscience 28:673-700.

-Scalzo FM, Ali SF, Holson RR, Williams RL (1993): Haloperidol effects on the developing dopamine system: conflicting results and implications for neurobehavioral teratology research. Ann Ist Super Sanita 29: 139-146.

-Scalzo FM, Spear LP (1985): Chronic haloperidol during development attenuates dopamine autoreceptor function in striatal and mesolimbic brain regions of young and older adult rats. Psychopharmacology (Berl) 85:271276.

-Schaefer TL, Skelton MR, Herring NR, Gudelsky GA, Vorhees CV, Williams MT (2008): Shortand long-term effects of $(+)$-methamphetamine and (+/-)-3,4-methylenedioxymethamphetamine on monoamine and corticosterone levels in the neonatal rat following multiple days of treatment. J Neurochem 104:1674-1685.

-Schambra UB, Duncan GE, Breese GR, Fornaretto MG, Caron MG, Fremeau RT Jr (1994): Ontogeny of $\mathrm{D}_{1 \mathrm{~A}}$ and $\mathrm{D}_{2}$ dopamine receptor subtypes in rat brain using in situ hybridization and receptor binding. Neuroscience 62: 65-85.

Schwartz CE, Snidman N, Kagan J (1999): Adolescent social anxiety as an outcome of inhibited temperament in childhood. J Am Acad Child Adolesc Psychiatry 38:10081015.

Segal M, Pickel V, Bloom F (1973): The projections of the nucleus locus coeruleus: an autoradiographic study. Life Sci 13:817-821.
Simansky KJ, Baker G, Kachelries WJ, Hood H, Romano AG, Harvey JA (1998): Prenatal exposure to cocaine reduces dopaminergic $\mathrm{D}_{1^{-}}$ mediated motor function but spares the enhancement of learning by amphetamine in rabbits. Ann NY Acad Sci 846:375-378.

-Simansky KJ, Kachelries WJ (1996): Prenatal exposure to cocaine selectively disrupts motor responding to $\mathrm{D}$-amphetamine in young and mature rabbits. Neuropharmacology 35:7178.

Singer LT, Minnes S, Short E, Arendt R, Farkas K, Lewis B, Klein N, Russ S, Min MO, Kirchner HL (2004): Cognitive outcomes of preschool children with prenatal cocaine exposure. JAMA 291:2448-2456.

- Singer LT, Nelson S, Short E, Min MO, Lewis B, Russ S, Minnes S (2008): Prenatal cocaine exposure: drug and environmental effects at 9 years. J Pediatr 153:105-111.

Singh KP, Singh M (2001): Effect of single prenatal haloperidol exposure on hippocampus and striatum of developing rat brain. Indian J Exp Biol 39:223-229.

Singh KP, Singh M (2002): Effect of prenatal haloperidol exposure on behavioral alterations in rats. Neurotoxicol Teratol 24:497-502.

-Skelton MR, Williams MT, Vorhees CV (2008): Developmental effects of 3,4-methylenedioxymethamphetamine: a review. Behav Pharmacol 19:91-111.

- Slamberova R, Bernaskova K, Matejovska I, Schutova B (2008): Does prenatal methamphetamine exposure affect seizure susceptibility in adult rats with acute administration of the same drug? Epilepsy Res 78:33-39.

Slotkin TA (1998): Fetal nicotine or cocaine exposure: which one is worse? J Pharmacol Exp Ther 285:931-945.

Slotkin TA (2004): Cholinergic systems in brain development and disruption by neurotoxicants: nicotine, environmental tobacco smoke, organophosphates. Toxicol Appl Pharmacol 198:132-151.

Slotkin TA, Kudlacz EM, Lappi SE, Tayyeb MI, Seidler FJ (1990): Fetal terbutaline exposure causes selective postnatal increases in cerebellar alpha-adrenergic receptor binding. Life Sci 47:2051-2057.

-Slotkin TA, Levin ED, Seidler FJ (2006): Comparative developmental neurotoxicity of organophosphate insecticides: effects on brain development are separable from systemic toxicity. Environ Health Perspect 114:746751.

-Slotkin TA, Seidler FJ (2007a): Developmental exposure to terbutaline and chlorpyrifos, separately or sequentially, elicits presynaptic serotonergic hyperactivity in juvenile and adolescent rats. Brain Res Bull 73:301-309.

-Slotkin TA, Seidler FJ (2007b): Prenatal chlorpyrifos exposure elicits presynaptic serotonergic and dopaminergic hyperactivity at adolescence: critical periods for regional and sex-selective effects. Reprod Toxicol 23:421427.
Slotkin TA, Tate CA, Cousins MM, Seidler FJ (2001): Beta-adrenoceptor signaling in the developing brain: sensitization or desensitization in response to terbutaline. Brain Res Dev Brain Res 131:113-125.

-Smith L, Yonekura ML, Wallace T, Berman N, Kuo J, Berkowitz C (2003): Effects of prenatal methamphetamine exposure on fetal growth and drug withdrawal symptoms in infants born at term. J Dev Behav Pediatr 24:17-23.

Smith LM, Chang L, Yonekura ML, Grob C, Osborn D, Ernst T (2001): Brain proton magnetic resonance spectroscopy in children exposed to methamphetamine in utero. Neurology 57:255-260.

- Smith LM, LaGasse LL, Derauf C, Grant P, Shah R, Arria A, Huestis M, Haning W, Strauss A, Della Grotta S, Liu J, Lester BM (2006): The infant development, environment, and lifestyle study: effects of prenatal methamphetamine exposure, polydrug exposure, and poverty on intrauterine growth. Pediatrics 118:1149-1156.

Smith LM, Lagasse LL, Derauf C, Grant P, Shah R, Arria A, Huestis M, Haning W, Strauss A, Grotta SD, Fallone M, Liu J, Lester BM (2008): Prenatal methamphetamine use and neonatal neurobehavioral outcome. Neurotoxicol Teratol 30:20-28.

Song ZM, Undie AS, Koh PO, Fang YY, Zhang L, Dracheva S, Sealfon SC, Lidow MS (2002): $D_{1}$ dopamine receptor regulation of microtubule-associated protein-2 phosphorylation in developing cerebral cortical neurons. J Neurosci 22:6092-6105.

Stanwood GD, Levitt P (2001): The effects of cocaine on the developing nervous system; in Nelson CA, Luciana M (eds): Handbook of Developmental Cognitive Neuroscience. MIT Press, pp 519-536.

-Stanwood GD, Levitt P (2003): Repeated i.v. cocaine exposure produces long-lasting behavioral sensitization in pregnant adults, but behavioral tolerance in their offspring. Neuroscience 122:579-583.

Stanwood GD, Levitt P (2004): Drug exposure early in life: functional repercussions of changing neuropharmacology during sensitive periods of brain development. Curr Opin Pharmacol 4:65-71.

-Stanwood GD, Levitt P (2007): Prenatal exposure to cocaine produces unique developmental and long-term adaptive changes in dopamine $D_{1}$ receptor activity and subcellular distribution. J Neurosci 27:152-157.

-Stanwood GD, Parlaman JP, Levitt P (2005): Anatomical abnormalities in dopaminoceptive regions of the cerebral cortex of dopamine $\mathrm{D}(1)$ receptor mutant mice. J Comp Neurol 487:270-282.

-Stanwood GD, Parlaman JP, Levitt P (2006): Genetic or pharmacological inactivation of the dopamine $D_{1}$ receptor differentially alters the expression of regulator of G-protein signalling (Rgs) transcripts. Eur J Neurosci 24: 806-818. 
-Stanwood GD, Washington RA, Levitt P (2001a): Identification of a sensitive period of prenatal cocaine exposure that alters the development of the anterior cingulate cortex. Cereb Cortex 11:430-440.

-Stanwood GD, Washington RA, Shumsky JS, Levitt P (2001b): Prenatal cocaine exposure produces consistent developmental alterations in dopamine-rich regions of the cerebral cortex. Neuroscience 106:5-14.

-Sundstrom E, Kolare S, Souverbie F, Samuelsson EB, Pschera H, Lunell NO, Seiger A (1993): Neurochemical differentiation of human bulbospinal monoaminergic neurons during the first trimester. Brain Res Dev Brain Res 75:1-12.

-Suzuki T, Mizuo K, Miyagawa K, Narita M (2005): Exposure to bisphenol-A affects the rewarding system in mice (in Japanese). $\mathrm{Ni}$ hon Shinkei Seishin Yakurigaku Zasshi 25: 125-128.

-Suzuki T, Mizuo K, Nakazawa H, Funae Y, Fushiki S, Fukushima S, Shirai T, Narita M (2003): Prenatal and neonatal exposure to bisphenol-A enhances the central dopamine $\mathrm{D}_{1}$ receptor-mediated action in mice: enhancement of the methamphetamine-induced abuse state. Neuroscience 117:639644.

-Szczerbak G, Nowak P, Kostrzewa RM, Brus R (2007): Maternal lead exposure produces long-term enhancement of dopaminergic reactivity in rat offspring. Neurochem Res 32 1791-1798.

- Tavares MA, Silva MC, Silva-Araujo A, Xavier MR, Ali SF (1996): Effects of prenatal exposure to amphetamine in the medial prefrontal cortex of the rat. Int J Dev Neurosci 14 585-596.

Thompson B, Stanwood G, Levitt P (2005a): Double dissociation of the reinforcing properties of cocaine. In: Society For Neuroscience, Washington, DC.

- Thompson BL, Levitt P, Stanwood GD (2005b): Prenatal cocaine exposure specifically alters spontaneous alternation behavior. Behav Brain Res 164:107-116.

Todd RD (1992): Neural development is regulated by classical neurotransmitters: dopamine $\mathrm{D}_{2}$ receptor stimulation enhances neurite outgrowth. Biol Psychiatry 31:794-807.
Tran TT, Chowanadisai W, Crinella FM, ChiczDeMet A, Lonnerdal B (2002): Effect of high dietary manganese intake of neonatal rats on tissue mineral accumulation, striatal dopamine levels, and neurodevelopmental status. Neurotoxicology 23:635-643.

Vorhees CV, Inman-Wood SL, Morford LL, Broening HW, Fukumura M, Moran MS (2000): Adult learning deficits after neonatal exposure to D-methamphetamine: selective effects on spatial navigation and memory. J Neurosci 20:4732-4739.

Vorhees CV, Skelton MR, Williams MT (2007): Age-dependent effects of neonatal methamphetamine exposure on spatial learning. Behav Pharmacol 18:549-562.

-Walderhaug E, Magnusson A, Neumeister A, Lappalainen J, Lunde H, Refsum H, Landro NI (2007): Interactive effects of sex and 5HTTLPR on mood and impulsivity during tryptophan depletion in healthy people. Biol Psychiatry 62:593-599.

-Wang HY, Runyan S, Yadin E, Friedman E (1995a): Prenatal exposure to cocaine selectively reduces $D_{1}$ dopamine receptor-mediated activation of striatal $G_{s}$ proteins. J Pharmacol Exp Ther 273:492-498.

-Wang JH, Yang JZ, Wilson FA, Ma YY (2006): Differently lasting effects of prenatal and postnatal chronic clozapine/haloperidol on activity and memory in mouse offspring. Pharmacol Biochem Behav 84:468-478.

-Wang XH, Levitt P, Grayson DR, Murphy EH (1995b): Intrauterine cocaine exposure of rabbits: persistent elevation of GABA-immunoreactive neurons in anterior cingulate cortex but not visual cortex. Brain Res 689: $32-46$.

-Wang XH, Levitt P, O’Brien-Jenkins A, Murphy EH (1996): Normal development of tyrosine hydroxylase and serotonin immunoreactive fibers innervating anterior cingulate cortex and visual cortex in rabbits exposed prenatally to cocaine. Brain Res 715:221-224.

Wasserman GA, Liu X, Parvez F, Ahsan H, Levy D, Factor-Litvak P, Kline J, van Geen A, Slavkovich V, LoIacono NJ, Cheng Z, Zheng Y, Graziano JH (2006): Water manganese exposure and children's intellectual function in Araihazar, Bangladesh. Environ Health Perspect 114:124-129.
Weissman AD, Caldecott-Hazard S (1993): In utero methamphetamine effects. I. Behavior and monoamine uptake sites in adult offspring. Synapse 13:241-250.

-Whitaker-Azmitia PM (2001): Serotonin and brain development: role in human developmental diseases. Brain Res Bull 56:479-485.

-White KJ, Walline CC, Barker EL (2005): Serotonin transporters: implications for antidepressant drug development. AAPS J 7:E421E433.

Williams MT, Morford LL, Wood SL, Rock SL, McCrea AE, Fukumura M, Wallace TL, Broening HW, Moran MS, Vorhees CV (2003): Developmental 3,4-methylenedioxymethamphetamine (MDMA) impairs sequential and spatial but not cued learning independent of growth, litter effects or injection stress. Brain Res 968:89-101.

Williams MT, Schaefer TL, Ehrman LA, Able JA, Gudelsky GA, Sah R, Vorhees CV (2005): 3,4Methylenedioxymethamphetamine administration on postnatal day 11 in rats increases pituitary-adrenal output and reduces striatal and hippocampal serotonin without altering SERT activity. Brain Res 1039:97-107.

-Won L, Bubula N, Heller A (2002): Fetal exposure to (+/-)-methylenedioxymethamphetamine in utero enhances the development and metabolism of serotonergic neurons in three-dimensional reaggregate tissue culture. Brain Res Dev Brain Res 137:67-73.

Yue Y, Widmer DA, Halladay AK, Cerretti DP, Wagner GC, Dreyer JL, Zhou R (1999): Specification of distinct dopaminergic neural pathways: roles of the Eph family receptor EphB1 and ligand ephrin-B2. J Neurosci 19: 2090-2101.

Zerrate MC, Pletnikov M, Connors SL, Vargas DL, Seidler FJ, Zimmerman AW, Slotkin TA, Pardo CA (2007): Neuroinflammation and behavioral abnormalities after neonatal terbutaline treatment in rats: implications for autism. J Pharmacol Exp Ther 322:16-22.

Zhang L, Bai J, Undie AS, Bergson C, Lidow MS (2005): $\mathrm{D}_{1}$ dopamine receptor regulation of the levels of the cell-cycle-controlling proteins, cyclin D, P27 and Raf-1, in cerebral cortical precursor cells is mediated through cAMP-independent pathways. Cereb Cortex 15:74-84. 